\title{
Ponthegesztő berendezés gyártása háztartási elektronikai hulladékból
}

\section{Manufacture of a Home-Made Spot Welding Machine from Household Electronic Waste}

\author{
Bíró Tamás, ${ }^{1}$ Renkó József Bálint ${ }^{2}$ \\ ${ }^{1}$ Budapesti Müszaki és Gazdaságtudományi Egyetem, Anyagtudomány és Technológia Tanszék \\ Budapest, Magyarország, biro.tamas@edu.bme.hu \\ ${ }^{2}$ Budapesti Müszaki és Gazdaságtudományi Egyetem, Anyagtudomány és Technológia Tanszék \\ Budapest, Magyarország, renko.jozsef@edu.bme.hu
}

\begin{abstract}
Nowadays, spot-welding technologies are being used on a very wide range of applications. Spot-welded joints can be found in many pieces of equipment, such as toasters, computers, telephone batteries, or even in various pre-manufactured car elements. Given the prevalence of the technology, there may be a legitimate need for a machine that can be used at home for simple spot-welding operations. Such a device could be produced more cost-effectively than those currently available on the market, while using household electronic waste. These could be produced for hobby purposes, thus creating an opportunity to recycle certain types of household electronic waste, thereby improving sustainability in an engineering approach.
\end{abstract}

Keywords: resistance spot welding, battery, sustainability.

\section{Összefoglalás}

Napjainkban a ponthegesztési eljárás igen széles körű alkalmazásnak örvend. Ponthegesztett kötésekkel lehet találkozni a hétköznapi élet számos területén: a kenyérpirítón, a számítógép vagy a telefon akkumulátorán, de akár autóipari karosszériaelemeken is. Tekintettel az eljárás elterjedtségére, jogosan merülhet fel az igény a hobbi barkácsműhelyben egy olyan ponthegesztő berendezés iránt, amely kis teljesítményü, de az egyszerű ponthegesztési műveletek elvégzésére alkalmas. Ilyen berendezések léteznek a piacon, ugyanakkor jelen cikk rávilágít arra, hogy költséghatékonyan, akár háztartási elektronikai hulladékok felhasználásával is előállítható a hobbicélokra jól használható ponthegesztő berendezés, lehetőséget teremtve ezzel bizonyos típusú háztartási elektronikai hulladékok újrahasznosítására, erősítve a fenntarthatóság érvényesülését is a mérnöki szemléletben.

Kulcsszavak: ponthegesztés, akkumulátor, fenntarthatóság.

\section{Bevezetés}

A folyamatosan növekvő fogyasztói igény gazdaságos kielégítése komoly kihívást jelent az ipar számára. A rendelkezésre álló erőforrások korlátozottsága arra ösztönzi a mérnököket, hogy új, fenntartható folyamatokat hozzanak létre, illetve a meglévőket továbbfejlesszék a kor elvárásainak megfelelően. A hegesztés is régi gyártási eljárásnak számít, ugyanakkor a 20. századtól kezdve folyamatos fejlődésen ment keresztül [1-3]. Napjainkra nemcsak ipari alkalmazásokban, hanem a legtöbb barkácsmühelyben is találkozhatunk ívhegesztő berendezésekkel. Ugyanakkor ez nem mondható el az ellenállás-hegesztés kapcsán, amelynek oka többek között e berendezések 
ára [4]. E cikk tárgyának, egy hobbi ponthegesztő berendezés elkészítésének ötletét egy gyakorlati problémára keresett megoldás hívta életre. Egy fúrógép meghibásodott akkumulátorának javítását akartuk elvégezni, ami tipikusan ponthegesztést igénylő művelet. Az alapötletet egy blogbejegyzés [5] adta, amelyben egy mikrohullámú sütő transzformátorát használták fel hasonló célokra. Munkánk során ezt a koncepciót akartuk továbbfejleszteni egy olyan ponthegesztő tervezésével, gyártásával és gyakorlati tesztelésével, amely zömében újrahasznosított alkatrészekből épül fel, és később - egy termékfejlesztési folyamat részeként - egy hobbicélokra jól használható, piacképes termék születhet belőle.

\section{Tervezés és gyártás}

A konstrukció kialakításával kapcsolatos munka egy részletes követelményjegyzék felállításával kezdődött, amely már létező berendezések jellemzőit figyelembe véve készült, ahol pedig ilyen nem állt rendelkezésre, a tervezési szempontok önkényesen kerültek meghatározásra [6-8]. Ilyen követelmény például (a teljesség igénye nélkül) a berendezés 230 V-os hálózatról történő üzemeltethetősége, IP 33-as védettség, az egyszerű felépítés, a mobilitás és a környezetvédelmi szempontok érvényesülésének biztosítása, a hegesztési idő és a hegesztési áramerősség szabályozhatósága. Ezen túl megköveteltük a szerkezettől, hogy képes legyen 0,1-0,15 mm-es lemezek közötti átlapolt kötések kialakítására. A következőkben a fontosabb részegységek konstrukciós kialakítását és gyártását mutatjuk be.

\subsection{A transzformátor kialakítása}

A hegesztőgép legfontosabb és legköltségesebb eleme a transzformátor, amely biztosítja a múvelethez szükséges kis feszültséget és nagy áramerősséget. Ezt egy meghibásodott mikrohullámú

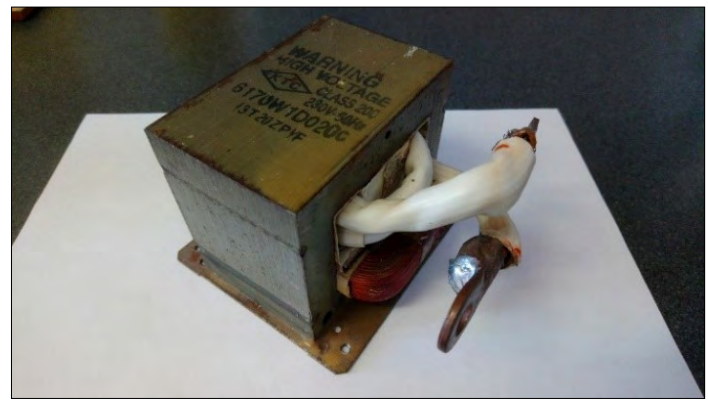

1. ábra. Új szekunder tekerccsel ellátott, egy mikrohullámú sütőből kiszerelt transzformátor sütőből nyertük ki, hiszen ezeknek a transzformátoroknak a jobb mágneses tulajdonságuk miatt nagyobb a teljesítménysürüségük, mint a hagyományos, lemezes, szerelt társaiknak, így a hegesztéshez szükséges áram tömeg- és helytakarékos módon biztosított. A bontott transzformátorból az eredeti szekunder tekercsének eltávolítása után a lehető legnagyobb vezeték-keresztmetszettel dolgozva kétmenetes szekunder tekercset alakítottunk ki. Az új tekercseléssel ellátott transzformátor az 1. ábrán látható.

\subsection{Vezérlőegység}

Mivel a berendezés elsősorban a hobbiigények kielégítésére, azon belül akkumulátorcellák csatlakozóinak ponthegesztésére készült, igen fontos a megfelelő hegesztési munkarend pontos betartása. Ehhez a hegesztőáram és a hegesztési idő állíthatóságát is biztosítani kellett [9, 10]. Ennek megvalósítására egy vezérlőáramkört terveztünk, amely egyszerű teljesítményelektronikai elemek felhasználásával készült. A hegesztés során alkalmazott áramerősség beállítása a fázishasítás elvén müködik [11, 12], a hegesztési idő változtatása pedig egy időzítő integrált áramkör [13] révén valósul meg. A 2. ábrán látható vezérlőpanel az áramköri terv nyáklapra laminálásával, illetve vegyi maratással készült, az alkatrészeket pedig a nyáklemez fúrása után lágyforrasztással építettük be.

\subsection{Burkolati elemek és perifériák}

A berendezés biztonságos és ergonomikus használatához szükség volt a megfelelő gépház és burkolati elemek mellett az elektródatartók és egy lábkapcsoló tervezésére is. A burkolathoz felhasznált lemezek szintén újrahasznosított elemei a gépnek, korábban egy hütőszekrény borításaként funkcionáltak. A hegesztéshez szükséges elektródanyomás kézi erővel biztosított, és jelenleg csak egyoldali, kétpontos hegesztést tesz lehe-

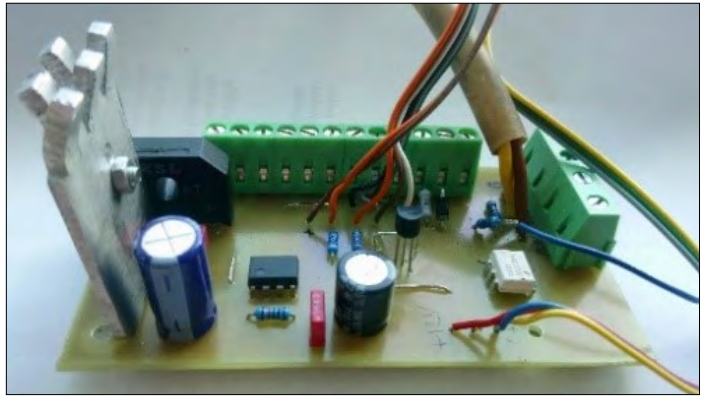

2. ábra. A hegesztőáram és a hegesztési idő állithatóságát megvalósító vezérlőegység 
tővé, ugyanakkor megfelelő adapter tervezésével kétoldali ponthegesztésre is alkalmassá tehető. Az elkészült ponthegesztőgép a 3. ábrán látható.

\section{Gyakorlati tesztelés és minősítés}

A termékfejlesztés igen fontos mozzanata volt a gyártás után a berendezés tesztelése. A célokban megfogalmazott követelmények teljesítését ugyanis ellenőrizni kellett. Ponthegesztett kötések vizsgálatára több eljárás is létezik [14], amelyek közül nyíró-szakító vizsgálatot végeztünk a varratok minősítésére. A próbatesteket $0,1 \mathrm{~mm}$, $0,2 \mathrm{~mm}$ és $0,3 \mathrm{~mm}$ vastagságú, S235JR anyagminőségű lemezek átlapolt kötésével alakítottuk ki. A hegesztési idő rendre 0,5 s, 1 s és 3 s volt, áramerősségnek pedig a berendezés által biztosított maximális érték lett beállítva. Az így meghatározott lemezvastagság-hegesztési idő párokból a 4. ábrán látható módon 10-10 próbahegesztést végeztünk. A pontvarratok elhelyezésénél figyelni kellett arra, hogy a nemkívánatos csavaró igénybevétel esetleges megjelenését és annak hatását minimalizálni tudjuk [9].

A minősítés kvalitatív módon, a próbatestek szakadási helyének makroszkópos vizsgálatával

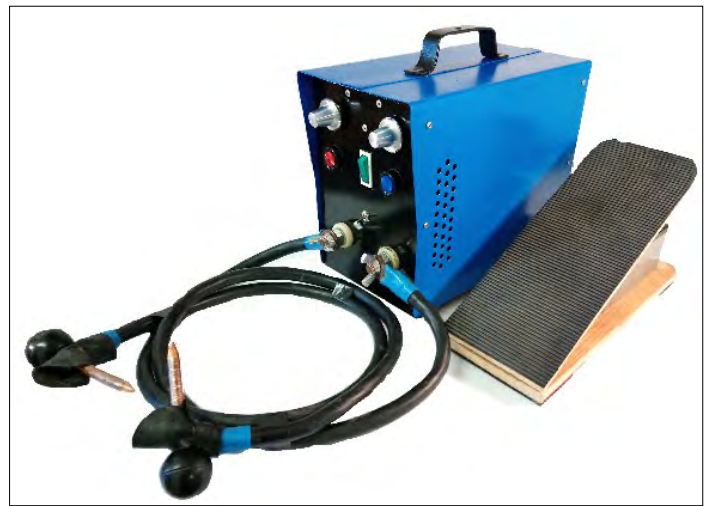

3. ábra. Az elkészült ponthegesztő a munkakábelekkel és elektródákkal, valamint a lábkapcsolóval

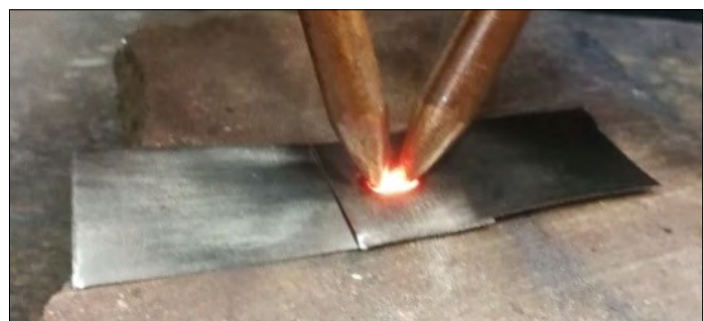

4. ábra. Próbatestek készítése nyíró-szakító vizsgálat számára történt. A szakítást $2 \mathrm{~mm} / \mathrm{min}$ sebességgel végeztük. Ezek alapján a berendezés - a hibás próbatesteket leszámítva (ahol a varratlencse a lemezpár teljes keresztmetszetében megolvadt) - a 0,1 mmes lemezeket 88\%-ban, a 0,2 mm-es lemezeket $77 \%$-ban, a $0,3 \mathrm{~mm}$-es lemezeket $0 \%$-ban hegesztette össze sikeresen. A hegesztés megfelelőségének feltétele az volt, hogy a varratok a terhelés hatására az alapanyagból kiszakadjanak, vagyis az ún. kigombolódás jelensége legyen tapasztalható (5. ábra).

A berendezés tesztelésének következő állomása az ipari gyakorlatban is felmerülő feladatok megoldása volt. A legtöbb, akkumulátorral üzemelő barkácsgépbe, laptopba ún. akkupakkok formájában építik be az akkumulátorcellákat, ezeket 99,97\%-os tisztaságú nikkelszalaggal kötik össze. Az elkészített ponthegesztő berendezéssel sikeresen hoztunk létre NiCd és Li-ion cellákból álló akkupakkokat a cellák meghibásodása [15] nélkül, sikeresen megoldva ezzel az alapötletet adó problémát (6. ábra). Így lehetőség nyílhat megjavítani azokat a berendezéseket, amelyeknél a gyári akkumulátor tönkremegy.

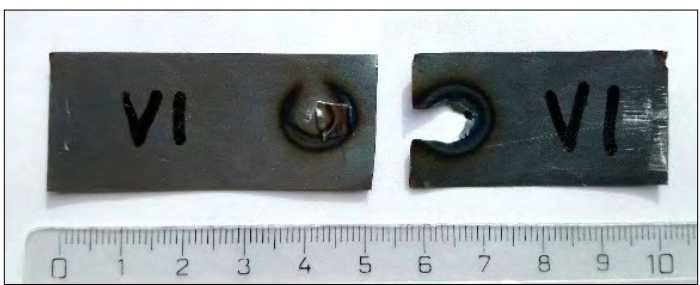

5. ábra. A kigombolódás jelensége egy 0,2 $\mathrm{mm}$ vastagságú lemezböl készült próbatest esetén

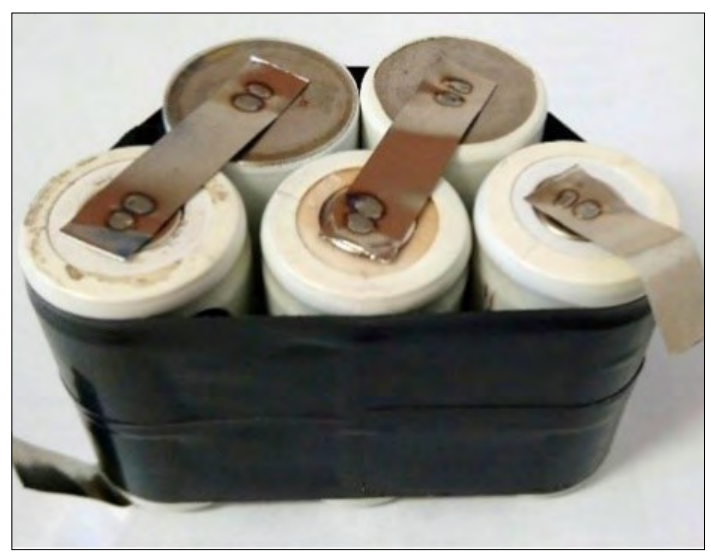

6. ábra. Az elkészített ponthegesztő berendezéssel létrehozott Ni-Cd akkupakk 


\section{Következtetések}

Számos lehetőség van a háztartásokban keletkező, sokszor veszélyes elektronikai hulladékok újrahasznosítására, azok megfelelő összegyüjtése és ártalmatlanítása után. Az itt bemutatott ponthegesztő gép erre egy lehetséges példa. Hangsúlyozandó ugyanakkor, hogy a megfelelő szakmai előismeretek és eszközök nélkül a megépítése körülményes, akár veszélyes is lehet. A létrehozott berendezés alkalmas akkumulátorcellák összekötésére, valamint maximum $0,2 \mathrm{~mm}$ vastag acéllemezek közötti átlapolt kötések kialakítására. Bár az újrahasznosított alkatrészeknek köszönhetően a gép előállítási költsége minimális egy kereskedelemben kapható hasonló berendezéshez képest, de ipari keretek között, kereskedelmi célra folytatott gyártás során egyéb költségek is felmerülhetnek. Kiemelendő ugyanakkor, hogy a konstrukciós kialakítás során a fenntarthatóságot igyekeztünk korszerű módon biztosítani.

\section{Köszönetnyilvánítás}

A publikáció az Emberi Erőforrások Minisztériuma NTP-SZKOLL-20-0067 kódszámú Nemzeti Tehetség Program pályázatának támogatásával valósult meg.

\section{Szakirodalmi hivatkozások}

[1] Schuler V., Twrdek J.: Praxiswissen Schweißtechnik. 6. Auflage. Springer Vieweg, Wiesbaden, 2019. 98-129.

[2] Artinger I., Kator L., Romvári P.: Fémek technológiája. 3. kiadás. Műszaki Könyvkiadó, Budapest, 1975. 306-393.

[3] Singh N. K., Vijayakumar Y.: Application of Taguchi method for optimization of resistance spot welding of austenitic stainless steel AISI 301L. Innovative Systems Design and Engineering, 3/10. (2012) 49-61.

[4] Hegesztéscentrum, Ponthegesztő gépek. 2019. https://hegesztescentrum.hu/ponthegeszto-gepek.html (letöltve: 2019. 10. 12.).
[5] Instructables workshop, MOT Spot Welder. 2013. https://www.instructables.com/id/MOT-SpotWelder-1/ (letöltve: 2019. 06. 14.).

[6] Payen G. R., Klöcker H., Lens A., Wilkinson D. S., Embury J. D.: Design of an in situ mechanical test for spotwelded joints, Engineering Fracture Mechanics, 96/12. (2013) 528-538. https://doi.org/10.1016/j.engfracmech.2012.09.002

[7] Han L., Thornton M., Boomer D., Shergold M.: A correlation study of mechanical strength of resistance spot welding of AA5754 aluminium alloy, Journal of Materials Processing Technology, 211/3. (2011) 513-521.

https://doi.org/10.1016/j.jmatprotec.2010.11.004

[8] Jou M.: Experimental Investigation of Resistance Spot Welding for Sheet Metals Used in Automotive Industry. JSME Int. Journal Series C Mechanical Systems, Machine Elements and Manufacturing, 44/2. (2001) 544-552.

https://doi.org/10.1299/jsmec.44.544

[9] Baránszky J. I.: Hegesztési kézikönyv. 1. kiadás. Müszaki Könyvkiadó, Budapest, 1985. 474-515.

[10] Habib Lebbal, Ahmed Reffas S., Habib Berrekia, Guagliano M.: Experimental Study of Spot Weld Parameters in Resistance Spot Welding Process. Mechanics and Mechanical Engineering, 22/1. (2020) 179-186.

https://doi.org/10.2478/mme-2018-0016

[11] Békei F., Stefanik P.: A rádiótechnika évkönyve 2004. 1. kiadás. Rádióvilág Kft., Budapest, 2004. 179-196.

[12] Békei F., Stefanik P.: A rádiótechnika évkönyve 2005. 1. kiadás. Rádióvilág Kft., Budapest, 2005. 196-207.

[13] Hainzmann J.: Elektronikus áramkörök. 3. kiadás. Tankönyvkiadó, Budapest, 2000. 450-453.

[14] MSZ EN ISO 14273:2002: Ellenállás-ponthegesztéssel, -vonalhegesztéssel és zömítö ellenállás-dudorhegesztéssel készített varratok nyíróvizsgálata és a próbatest méretei. 2002.

[15] Brand M., Keil P., Grubwinkler S., Jossen A., Lienkamp M.: Entwicklung und Diskussion ein er 12V-Pufferbatterie aus LiFePo4-Akkumulatoren. 19. Design\&Elektronik-Entwicklerforum Batterien \& Ladekonzepte, München, 2012. 